\title{
REKONSTRUKSI PEMBAGIAN TUGAS DAN WEWENANG KPPS (KELOMPOK PENYELENGGARA PEMUNGUTAN SUARA) PASCA PEMILU TAHUN 2019
}

\author{
Riki Rahmad \\ rikirahmad@gmail.com \\ Khairul Fahmi \\ Fakultas Hukum Universitas Andalas \\ fahmi@pusako.or.id
}

Fakultas Ilmu Sosial dan Politik Universitas Andalas

DOI: $10.23917 /$ jjr.v9i2.8143

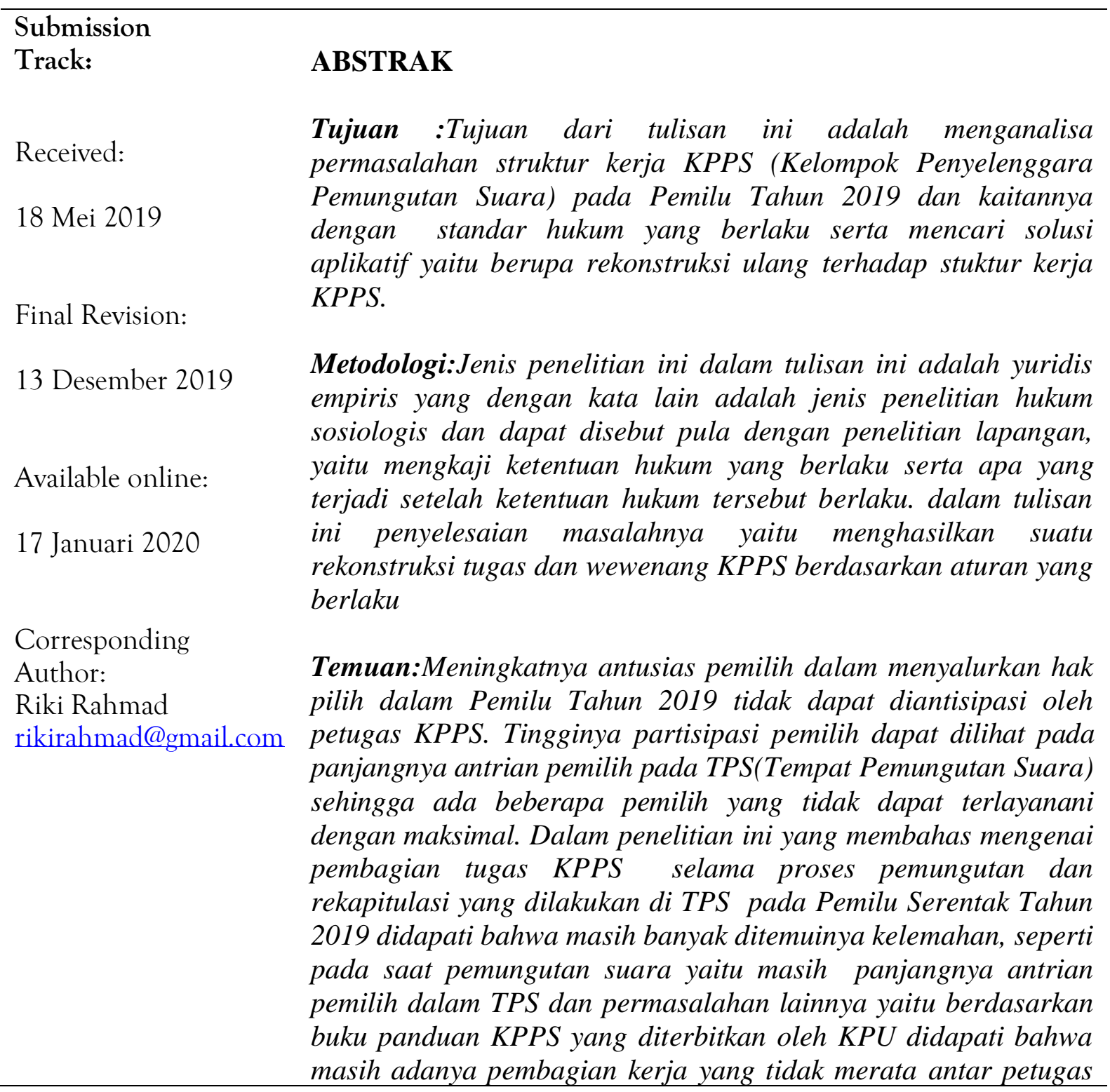


KPPS. Permasalahan pada saat rekapitulasi suara yaitu masih diperlukan waktu yang panjang bahkan sampai larut malam mengakibatkan proses tersebut menjadi tidak efektif dan efisien dan berakibat pada permasalahan hukum nantinya

Kegunaan:Diharapkan dengan adanya rekonstruksi ulang tersebut maka proses pemungutan dan rekapitulasi surat suara bisa sesuai dengan standar hukum yang ada sehingga hasil dari rekapitulasi ditingkat TPS dapat diuji tingkat validitas dan keakurantannya.

Kebaruan/Orisinalitas:Beberapa penelitan yang membahas mengenai pembagian tugas KPPS masih banyak kekurangannya dan juga masalah yang dibahas hanyalah pembagian tugas KPPS pada pemilu tahun 2014 yang mana beban tugas KPPS antara Pemilu Tahun 2014 dan Pemilu Tahun 2019 tentu saja berbeda yang menggunakan 5 (lima) surat suara berbeda.

Keywords : Rekonstruksi KPPS, Evaluasi KPPS, Penyelenggara Pemilu 2019

\section{ABSTRACT}

Purpose of the study :The purpose of this paper is to analyze the problem of the work structure of the KPPS (Voting Organizers Group) in the 2019 Elections in Indonesia and the relation to applicable legal standards and to find applicative solutions in the form of reconstruction of the KPPS work structure.

Methodology:This type of research in this paper is empirical juridical which in other words is a type of sociological legal research and can also be referred to as field research, which examines the applicable legal provisions and what happens after the legal provisions apply. in this paper, the solution to the problem is to produce a reconstruction of the KPPS duties and authority based on the applicable rules.

Results:The increasing enthusiasm of voters in distributing their voting rights in the 2019 Elections could not be anticipated by KPPS officers. The high turnout of voters can be seen in the length of the queue of voters at the TPS (polling stations) so that there are some voters who cannot be served optimally. In this research that discusses the division of tasks of the KPPS during the polling and recapitulation carried out at the TPS in the 2019 Simultaneous Elections, it was found that there were still many weaknesses found, such as during the voting namely the long queue of voters in the polling station and other problems namely 
based on the KPPS handbook published by KPU found that there was still an unequal division of work among KPPS officers. The problem at the time of the vote recapitulation is that it still takes a long time even until late at night resulting in the process being ineffective and inefficient and resulting in legal problems later

Applications of this study:It is expected that with the rereconstruction the ballot collection and recapitulation process can be in accordance with existing legal standards so that the results of the recapitulation at the TPS level can be tested for their validity and accuracy.

Novelty/ Orginalty of this study:Some researches discussing the division of tasks of the KPPS are still many shortcomings and also the problem discussed is the division of tasks of the KPPS in the 2014 elections where the burden of KPPS tasks between the 2014 and 2019 elections is of course different which uses 5 (five) ballots are different.

Keywords: : Reconstruction of KPPS, Evaluation of KPPS, 2019 Election Organizer

\section{PENDAHULUAN}

KPPS (Kelompok Pemungutan dan Penghitungan Suara) merupakan ujung tombak dari pelaksanaan Pemilu ditingkat yang paling bawah, kunci suksesnya suatu Pemilu ada ditangan KPPS. Hasil kerja KPU Kabupaten/Kota, KPU Provinsi dan KPU sepenuhnya bergantung pada kualitas hasil kerja KPPS, PPS, dan PPK karena tugas KPU Kabupaten/Kota, KPU Provinsi, dan KPU hanya menjumlahkan hasil pemungutan suara di bawahnya. Oleh karena itu, kualitas anggota dan ketua KPPS, PPS, dan PPK harus memadai sesuai dengan bidang tugasnya, dan proses pelaksanaan tugas dan kewenangan mereka harus pula sesuai dengan asas-asas pemilihan umum yang demokratik (Surbakti \& Nugroho, 2015). Pemilu Tahun 2019 adalah pemilu serentak yang menggabungkan antara pemilihan Anggota Legislatif dari tingkat pusat sampai daerah dan juga Pemilihan Presiden dan wakil Presiden. Metode semacam ini belum pernah dilakukan sebelumnya baik di Indonesia maupun belahan dunia lainnya, oleh karena itu banyak pemerhati Pemilu menganggap Pemilu Tahun 2019 ini merupakan Pemilu Terumit di Dunia. Salah satu konsekuensinya dari Pemilu serentak ini 
adalah surat suara yang digunakan menjadi lebih banyak. Berdasarkan aturan yang berlaku untuk Pemilu Tahun 2019 ini saja membutuhkan lima jenis surat suara. KPPS dituntut untuk bisa memahami alur kerja dan sistem pemungutan suara secara singkat karena waktu antara Perekrutan KPPS dilanjutkan dengan Bimbingan dilanjutkan dengan proses pelaksanaan pemungutan suara dilakukan terlalu singkat.

Pada Pemilu Serentak Tahun 2019 ini setelah proses rekapitulasi suara di TPS, KPU dihadapkan dengan kenyataan bahwa banyak sekali petugas KPPS yang meninggal dunia akibat kelelahan saat bertugas, bahkan ada yang bunuh diri akibat stres. Berdasarkan fakta dilapangan dan rumitnya proses pemungutan dan rekapitulasi pada pemilihan umum tahun ini, maka tidak kaget adanya berita petugas KPPS yang meninggal dunia bahkan bunuh diri. Karena memang sistem pemilu kita sangat melelahkan bagi penyelenggara khususnya bagi KPPS yang berada di tataran operasional. Berdasarkan sumber dari KPU jumlah anggota KPPS yang meninggal pertanggal 16 Mei 2019 berjumlah 486 orang dan sakit berjumlah 4.849 orang, belum lagi ditambah korban meninggal dari pihak kepolisian dan Bawaslu dan mungkin jumlah dari korban pesta demokrasi ini akan semakin meningkat.(detiknews, 2019)

Proses Rekapitulasi yang membutuhkan banyak tenaga, dengan banyaknya formulir yang harus diisi oleh KPPS seperti 60 halaman C1 Plano, 28 halaman formulir C1 hologram ditambah 46 rangkap salinan C1 dikali 28 halaman. Melihat banyaknya formulir yang harus diisi oleh KPPS maka dibutuhkan KPPS yang mampu bekerja sama satu dengan yang lain sesuai yang disampaikan oleh (Sugihariyadi \& Rahardjo, 2015) tentang indikasi seorang penyelenggara pemilu layak dianggap profesional harus memiliki ciri-ciri: (a) memiliki kemampuan atau keterampilan dalam menggunakan peralatan yang berhubungan dengan bidang pekerjaan; (b) memiliki ilmu dan pengalaman dalam menganalisis; (c) bekerja di bawah disiplin kerja; (d) mampu melakukan pendekatan disipliner; (e) mampu bekerja sama; dan (f) cepat tanggap terhadap masalah.

Pembagian tugas yang adil dan merata antar anggota KPPS khususnya dalam pengisian formulir sehingga proses dari rekapitulasi surat suara bisa cepat terselesaikan dan tidak makan waktu hingga 24 jam bahkan lebih. Penulis melihat lamanya proses rekapitulasi salah satunya dikarenakan pada proses penyalinan hasil C1 Plano kepada formulir C1 yang berjumlah total 84 lembar tersebut jika semua diisi dan semua saksi hadir membutuhkan waktu lama. Diperlukan kajian yang lebih mendalam tentang alur kerja dan struktur kerja anggota KPPS yang ada pada buku panduan KPPS dan melakukan perubahan terhadap 
pembagian kerja sehingga membuat proses pemungutan dan rekapitulasi bisa berjalan cepat dan tepat waktu.

Permasalahan lainnya dalam proses pemungutan dan rekapitulasi surat suara yang dilakukan oleh KPPS masih banyak petugas Ketertiban TPS yang diperbantukan untuk membantu tugas dari KPPS, ini merupakan dampak dari banyak dan rumitnya tugas KPPS sehingga harus dibantu oleh Petugas Ketertiban TPS yang merupakan diluar tugas mereka. Sesuai dengan buku pedoman KPPS yang diterbitkan oleh KPU Petugas Ketertiban memiliki tugas yaitu menjaga ketentraman, ketertiban dan kemanan di pintu masuk dan keluar TPS, tetapi dilapangan masih banyak petugas Ketertiban TPS yang ditambahi tugas membantu tugas KPPS lainnya.

Penelitian sebelumnya mengenai pengaturan ulang tata kerja KPPS pada saat pemungutan dan rekapitulasi surat suarat di TPS telah banyak dilakukan seperti penelitian yag dilakukan oleh (Susanto, 2014) yang mengangkat tema Disproporsionalitas beban tugas KPPS Studi Integritas Pemilu. Dalam penelitian tersebut lebih menekankan kepada mencari kelemahan desain pembagian tugas KPPS pemilu legislatif tahun 2014, dan menawarkan solusi terbaik yang mampu mencegah dan mengurangi irregularity dan electoral malpractice. Penelitian yang penulis lakukan hampir sama dengan penelitian diatas, akan tetapi penelitan diatas masih banyak kekurangan dalam hal pembagian tugas KPPS. Oleh karena itu, penulis mencoba untuk lebih memberikan solusi yang aplikatif mengenai pembagian kerja KPPS apalagi dihubungkan dengan momen Pemilu Seretak Tahun 2019 yang merupakan Pemilu Terumit Didunia. Diharapkan penelitian ini bisa nantinya bisa dijadikan referensi untuk pengaturan atau pembagian beban tugas dan tanggung jawab KPPS selama Pemungutan dan Rekapitulasi suara di TPS untuk Pemilu yang akan datang.

\section{METODELOGI PENELITIAN}

Jenis penelitian ini dalam tulisan ini adalah yuridis empiris yang dengan kata lain adalah jenis penelitian hukum sosiologis dan dapat disebut pula dengan penelitian lapangan, yaitu mengkaji ketentuan hukum yang berlaku serta apa yang terjadi setelah ketentuan hukum tersebut berlaku. Maksudnya adalah suatu penelitian yan dilakukan terhadap keadaan sebenarnya tau keadaan nyata yang terjadi dimasyarakat dengan maksud untuk mengetahui dan menemukan fakta-fakta dan data yang dibutuhkan, setelah data yang dibutuhkan 
terkumpul kemudian menuju identifikasi masalah yang pada akhirnya menuju pada penyelesaian masalah dalam tulisan ini penyelesaian masalahnya yaitu menghasilkan suatu rekonstruksi tugas dan wewenang KPPS berdasarkan aturan yang berlaku.

Penelitian sosiologi hukum juga membutuhkan kombinasi yang integral dalam pengambilan kesimpulan dari berbagai disiplin ilmu. Penelitian seperti ini biasa dikenal dengan penelitian multidisipliner atau penelitian interdisipliner atau penelitian transdisipliner.Pendekatan yang dipakai adalah pendekatan yuridis sosiologis yaitu menekankan penelitian yang bertujuan untuk memperoleh pengetahuan hukum secara empiris dengan jalan terjun langsung ke objeknya yaitu mengetahui persoalan ketidak sesuaian antara beban kerja KPPS dilapangan dengan standar pedoman kerja KPPS yang ada pada buku panduan KPPS.

\section{PEMBAHASAN}

KPPS yang berjumlah tujuh orang disetiap TPS harus memiliki pemahaman yang sama terhadap proses pemungutan dan rekapitulasi suara, mereka mempunyai beban dan tekanan yang tinggi baik dari pihak penyelenggara diatasnya seperti PPS, PPK dan KPU, dan juga dari pihak Bawaslu yang mengawasi gerak-gerik mereka selama proses Pemungutan Suara didalam TPS belum lagi tekanan dari pihak luar seperti para peserta Pemilu dan saksisaksi mereka.

Kurangnya pemahaman antaraanggota KPPS berakibat kepada terjadi Pemungutan Suara Ulang (PSU) seperti yang terjadi di Sumatera Barat adanya sejumlah temuan oleh pengawas pemilu dan memiliki konsekuensi PSU. Rata-rata persoalannya, ada sejumlah pemilih yang menggunakan KTP, tapi tidak berdomisili di daerah tersebut. Selain itu, juga terjadi salah kaprah panitia atau pemahaman cara penghitungan suara, namun begitu secara keseluruhan hanya persoalan administrasi yang terjadi. Hal yang sama juga dikatakan oleh Anggota Bawaslu Padang Firdaus Yusri, setelah terjadi proses pemilihan baru panitia mengetahui bahwa ada pemilih yang bukan KTP Padang. Setelah pemungutan suara, dan dihitung, baru diketahui ada daftar pemilih di luar KTP setempat (klikpositif.com, 2019).

Proses Pemungutan dan rekapitulasi yang terlalu rumit dan melelahkan karena pemilihan Presiden dan Legislatif yang dilakukan secara serentak menambah beban kerja KPPS sehingga dikhawatirkan mengurangi validitas dan akurasi hasil pemilu itu sendiri seperti yang disampaikan (Nasaruddin, Mone, \& Hamrun, 2017) Penyelenggara pemilu berpeluang 
melakukan kesalahan akibat penyalahgunaan kekuasaan atau bahkan karena kelalaian. Begitu juga dengan peserta, pemaknaan pemilu sebagai kompetisi justru akan menjebak mereka pada ruang pertarungan bebas antar kandidat. Anggota KPPS yang mendapat beban pekerjaan besar adalah ketua, anggota kedua, dan ketiga. Tugas ketua KPPS paling banyak diantara yang lain, memimpin proses penghitungan suara, mengisi formulir, serta mengumumkan sah/tidak tanda coblos pada surat suara dengan suara keras dan jelas. Tugas anggota KPPS kedua dan KPPS ketiga juga berat karena harus mengisi formulir C1 (sertifikat hasil penghitungan suara) dengan proses pengisian yang rumit sejumlah 17 rangkap. Anggota KPPS keempat dan KPPS kelima hanya mengisi formulir C1 plano, serta anggota KPPS keenam dan KPPS ketujuh hanya mengelompokkan suara sah/tidak sah (Susanto, 2014). Beranjak dari permasalahan diatas perlu dianalisa dan identifikasi faktor-faktor yang mengakibatkan proses pemungutan dan rekapitulasi surat suara menjadi terkendala ditinjau dari struktur kerja KPPS sehingga nantinya didapatkan struktur pembagian kerja yang efektif dan efisien.

\section{Permasalahan Pada Proses Pemungutan Suara}

KPPS dibekali oleh buku panduan KPPS yang diterbitkan oleh (KPU, 2019)yang digunakan sebagai standar atau pedoman dalam melaksanakan Tugas di TPS. Buku Pedoman Tersebut menyebutkan bahwa tugas KPPS salah satunya adalah dalam rangka mewujudkan kedaulatan pemilih, melayani pemilih menggunakan hak pilih, memberikan akses dan layanan kepada Pemilih disabilitas dalam memberikan hak pilihnya. Dasar hukum dari buku pedoman KPPS tersebut adalah Peraturan KPU No.3 Tahun 2019 mengenai pemungutan dan penghitungan suara Pemilahan Umum. Struktur kerja KPPS yang ada dalam buku panduan KPPS tersebut perlu dikaji lebih dalam apakah sesuai dengan standar hukum secara internasional mengenai pelaksanaan pemungutan suara yang diterbitkan oleh (IDEA, 2002) Kerangka hukum harus secara jelas menetapkan tugas dan fungsi badan pelaksana pemilu terutama KPPS. Tugas dan fungsi ini harus secara khusus mencakup hal berikut :

a) Apakah kerangka hukum menjamin bahwa suara diberikan dengan kertas suara yang rahasia?

b) Apakah ada larangan terhadap "pemberian suara secara berkelompok"? 
c) Apakah kerangka hukum pemilu mengharuskan para pemilih diidentifikasi secara memadai sebelum menerima kertas suara?

d) Apakah kerangka hukum memuat ketentuan yang memadai untuk keamanan semua kertas suara dan materi pemungutan suara sebelum, selama dan setelah pemungutan suara?

e) Apakah kerangka hukum memberikan metode pemungutan suara alternatif untuk orangorang tertentu atau orang-orang dengan kategori tertentu?

f) Apakah kerangka hukum memuat pencegahan terhadap kecurangan atau pemberian suara ganda?

g) Apakah kerangka hukum mencegah seseorang menggunakan metode alternatif atau proses biasa untuk memberikan suara dua kali dalam pemilu yang sama?

h) Apakah kerangka hukum melarang masuknya polisi atau angkatan bersenjata secara rutin ke dalam tempat pemungutan suara kecuali untuk memberikan suara atau apabila mereka secara khusus diberikan wewenang oleh orang yang bertanggung jawab atas tempat pemungutan suara untuk memulihkan ketertiban?

Rincian standar hukum pelaksanaan pemungutan suara yang diterbitkan oleh IDEA tersebut menjadi salah satu patokan bagi KPPS untuk melaksanakan proses pemungutan suara, jika ada KPPS yang melanggar atau tidak melaksanakan rincian standar hukum tersebut maka bisa dikatakan proses pemungutan suara di TPS tersebut menjadi tidak profesional dan berintegritas. Disisi lain dengan banyaknya standar hukum yang ada dan harus dipatuhi oleh KPPS mengharuskan KPPS harus teliti dan cermat, apalagi proses tersebut diawasi oleh Panwas TPS dan para saksi. Banyaknya standar hukum yang harus dipatuhi oleh KPPS dalam menjalankan tugas maka juga berdampak pada pembagian tugas yang harus proporsional antar petugas KPS. Dikhawatirkan jika tidak dilakukan pembagian tugas antar KPPS bisa membuat proses pemungutan suara tersebut hanya bertumpu pada satu atau dua orang saja sedangkan petugas lain tidak memaksimalkan kinerja, kejadian tersebut masih banyak terjadi pada Pemilu Tahun 2019 ini.

Permasalahan pada tahapan pemungutan suara yang terjadi di lapangan adalah seiring dengan Pemilu Serentak Tahun 2019 apalagi dihadapkan dengan Pemilihan Capres dan Cawapres yang berhadapan antara dua pasangan calon maka berefek kepada antusiasme pemilih dalam memberikan haksuara mereka menjadi meningkat, sehingga antrian pemilih pada TPS menjadi panjang. Kejadian tersebut tidak bisa diantisipai oleh pihak KPPS sehingga banyak 
pemilih yang mengeluh antri selama satu atau dua jam hanya untuk menyalurkan hak pilih mereka, padahal kejadian tersebut tidak pernah terjadi pada Pemilu atau Pilkada sebelumnya.

Pembagian tugas yang hanya bertumpu pada satu atau dua orang saja maka berakibat kepada terlantarnya pemilih dalam TPS sehingga ruangan TPS tidak bisa lagi menampung antrian pemilih, ada beberapa pemilih yang memilih pulang atau melanjutkan pekerjaan lainnya padahal sebelumnya mereka sudah mengisi daftar hadir. Kenyataan dilapangan bahwa ketua KPPS terlalu sibuk untuk mengurus administrasi dalam KPPS seperti menandatangani surat suara dan lainnya sehingga ketua KPPS menjadi lupa untuk melihat bahwa ada bilik suara yang kosong yang bisa digunakan pemilih yang sudah lama antri. Pembagian tugas lain ada beberapa anggota KPPS yang belum dimaksimalkan kinerjanya seperti pada anggota KPPS 7 yang hanya duduk untuk mengarahkan pemilih mencelupkan jarinya ketinta. Seharusnya tugas KPPS 7 ini dapat dialihkan untuk membantu ketua KPPS dalam hal memberikan kode atau tanda kepada ketua KPPS bahwasanya ada bilik suara yang kosong yang bisa digunakan pemilih sehingga perputaran dari proses penghitungan suara cepat selesai sesuai waktu yang ditentukan.

\section{Permasalahan Pada Proses Rekapitulasi Surat Suara}

Proses rekapitulasi suara memerlukan tingkat konsentrasi dan ketelitian oleh KPPS, karena melalui proses rekapitulasi inilah penentuan jumlah suara yang didapat oleh peserta Pemilu dan jangan sampai salah input ataupun memanipulasi data yang ada dan akan berdampak hukum nantinya. Menurut (Surbakti \& Karim, 2014) bahwa pelanggaran pidana pemilu pada saat penghitungan dan rekapitulasi suara menjadi terbuka jika petugas pemilu tidak memiliki integritas.

Dalam standar hukum yang mengatur tentang Rekapitulasi salah satunya (IDEA, 2002) yang telah memberikan daftar periksa yang bisa menjadi pedoman bagi penyelenggara Pemilu dalam proses rekapitulasi surat suara antara lain :

a) Apakah kerangka hukum memastikan seluruh proses penghitungan dan pentabulasian suara dilakukan dengan kehadiran perwakilan partai dan kandidat serta pemantau dan perwakilan dari media?

b) Saat perhitungan suara dilakukan dengan cara yang tidak manual, apakah kerangka hukum menentukan verifikasi independen dari semua perangkat keras, perangkat lunak, dan unsur-unsur lain dalam proses penghitungan dan pentabulasian? 
c) Apakah undang-undang mengharuskan semua tabulasi dibuat dalam bentuk yang memungkinkan perwakilan partai dan kandidat serta pemantau untuk melacak penghitungan suara di setiap tempat pemungutan suara sampai ke atas, sampai ke hasil konsolidasi final?

d) Apakah undang-undang mengharuskan agar tabulasi hasil memuat informasi terperinci tentang hasil untuk semua metode pemungutan suara tanpa mengancam kerahasiaan kertas suara?

e) Apakah undang-undang mengharuskan pengumuman dan publikasi di media cetak atas hasil-hasil terperinci dari tingkat tempat pemungutan suara sampai dengan badan pelaksana pemilu pusat?

f) Apakah undang-undang menjelaskan proses pengesahan final dari hasil pemilu dan pemberitahuan kepada para kandidat, serta masa kerja para kandidat terpilih?

g) Apakah semua persyaratan dan prosedur penghitungan ulang kertas suara dijelaskan?

h) Apakah semua persyaratan dan prosedur pemilihan baru dijelaskan?

Pedoman hukum yang diterbitkan oleh (IDEA, 2002) tersebut jika dihubungkan dengan pedoman tata cara rekapitulasi suara yang ada pada buku pedoman KPPS masih banyak yang perlu perbaikan untuk kesempurnaan tugas KPPS di Pemilu yang akan datang. Permasalahan di lapangan adalah masih banyaknya waktu yang dibutuhkan untuk proses rekapitulasi ini bahkan ada yang melewati batas 24 jam untuk semua proses di TPS tersebut. Penyebab utamanya adalah tidak semua sumber daya anggota KPPS yang dilibatkan dalam proses rekapitulasi tersebut. Contohnya adalah untuk penyalinan kembali isi dari model $\mathrm{C} 1$ plano kedalam 28 halaman formulir C1 hologram ditambah 46 rangkap salinan C1 dikali 28 halaman berdasarkan buku pedoman KPPS itu dibutuhkan waktu khusus untuk mengisi formulir tersebut. Pengisian formulir tersebut dilakukan setelah model C1 Plano disetujui oleh Panwas TPS dan para saksi dan formulir yang banyak tersebut disalin oleh ketua KPPS dibantu anggota KPPS 2, KPPS 3, KPPS 4, dan KPPS 5 kedalam masing-masing formulir Model C1 hologram beserta salinannya sesuai jenis Pemilu dan ditandatangani oleh Ketua KPPS, anggota KPPS dan Saksi Peserta Pemilu yang hadir.

Permasalahan tersebut banyak dikeluhkan oleh KPPS sehingga ada beberapa ketua KPPS berinisiatif dengan persetujuan panwas TPS dan para saksi mengubah susunan tata kerja rekapitulasi dengan menugaskan satu atau dua orang KPPS terutama perempuan untuk 
langsung menyalin isi C1 Plano ketika model C1 Plano tersebut diisi pada papan yang tersedia di TPS kedalam formulir C1beserta lampirannya, Sehingga ketika C1 Plano selesai dikerjakan begitu juga formulir $\mathrm{C} 1$ dapat diselesaikan juga dan dilanjutkan dengan ditandatangi secara beriringan antara model $\mathrm{C} 1$ Plano dengan formulir $\mathrm{C} 1$ sehingga bisa menghemat waktu tidak perlu waktu hingga 24 jam menyelesaikan rekapitulasi tersebut.

\section{Rekomendasi Pembagian Tugas KPPS}

Pembagian tugas KPPS yang ada Indonesia pada saat Pemilu 2019 berdasarkan buku pedoman KPPS yang diterbitkan oleh KPU ketika proses Pemungutan suara di TPS ada beberapa rekomendasi yang dapat diberikan pada tulisan ini terutama pada tugas KPPS 6 dan KPPS 7. Pembagian tugas ini bertujuan agar nantinya semua pemilih dapat tersalurkan hak pilihnya dan juga sesuai dengan standar hukumpelaksanaan pemungutan suarayang diterbitkan oleh (IDEA, 2002). Pembagian tugasnya yaitu mengalihkan tugas dari KPPS 7 yang semula duduk mengarahkan pemilih mencelupkan jari ke tinta ke posisi disebelah KPPS 6 membantu mengarahkan pemilih memasukkan surat suara ke kotak suara sesuai jenis pemilihan dan memberikan isyarat atau pertanda kepada ketua KPPS bahwasanya ada bilik yang kosong yang bisa digunakan Pemilih. Rincian Rekomendasi pada Proses Pemungutan suara dapat dilihat pada tabel 1 :

Tabel 1. Tabel Rekomendasi Pembagian tugas KPPS Pada Proses Pemungutan Suara

\begin{tabular}{|c|c|c|}
\hline Jabatan & Tugas & Rekomendasi \\
\hline $\begin{array}{l}\text { Ketua } \\
\text { (KPPS 1) }\end{array}$ & $\begin{array}{l}\text { a) Memimpin rapat pemungutan suara. } \\
\text { b) Memberikan penjelasan kepada Pemilih } \\
\text { tentang tata cara pemberian suara. } \\
\text { c) Menandatangani Surat Suara yang akan } \\
\text { digunakan. } \\
\text { d) Memberikan Surat Suara kepada Pemilih. } \\
\text { e) Mengarahkan Pemilih ke bilik suara }\end{array}$ & Tidak ada \\
\hline KPPS 2 & $\begin{array}{l}\text { a) Menerima dari anggota KPPS 5: } \\
\text { 1) Model C6-KPU untuk Pemilih DPT. } \\
\text { 2) KTP-el/Suket/KK/Paspor/SIM untuk } \\
\text { Pemilih DPT yang tidak membawa } \\
\text { formulir Model C6-KPU. } \\
\text { 3) Model A.5-KPU/A.5 LN-KPU untuk } \\
\text { Pemilih DPTb. } \\
\text { 4) KTP-el untuk Pemilih DPK. } \\
\text { b) Mengisi nama Kecamatan, }\end{array}$ & Tidak ada \\
\hline
\end{tabular}




\begin{tabular}{|c|c|c|}
\hline & $\begin{array}{l}\text { Kelurahan/Desa, dan nomor TPS pada } \\
\text { Surat Suara. } \\
\text { c) Membantu tugas Ketua KPPS. }\end{array}$ & \\
\hline KPPS 3 & $\begin{array}{l}\text { a) Mengumpulkan: } \\
\text { 1) Model C6-KPU Pemilih DPT. } \\
\text { 2) Model A.5-KPU/A.5 LN-KPU Pemilih } \\
\text { DPTb. } \\
\text { b) Mengisi nama Kecamatan, } \\
\text { Kelurahan/Desa, dan nomor TPS pada } \\
\text { Surat Suara. } \\
\text { c) } \\
\text { Membantu tugas Ketua KPPS. }\end{array}$ & Tidak ada \\
\hline KPPS 4 & $\begin{array}{l}\text { a) Memeriksa seluruh jari tangan pemilih. } \\
\text { b) Menerima dan memeriksa KTP- } \\
\text { el/Suket/KK/Paspor/SIM dengan formulir } \\
\text { Model C6-KPU untuk Pemilih DPT dan } \\
\text { model A5 bagi Pemilih DPTb dan hanya } \\
\text { KTP-el bagi Pemilih DPK. } \\
\text { c) Memeriksa kesesuain nama Pemilih } \\
\text { bersangkutan dengan Nama Pemilih yang } \\
\text { tercantum dalam formulir Model A.3- } \\
\text { KPU/Model A.4-KPU. } \\
\text { d) Mencatat: } \\
\text { 1) nama Pemilih DPTb ke dalam formulir } \\
\text { Model A.4-KPU sesuai nomor urut } \\
\text { berikutnya, apabila nama pemilih } \\
\text { DPTb bersangkutan belum sempat } \\
\text { melapor ke PPS tujuan. } \\
\text { 2) nama Pemilih DPK ke dalam formulir } \\
\text { Model A.DPK-KPU sesuai nomor urut } \\
\text { berikutnya, apabila nama } \\
\text { Pemilih tersebut belum terdaftar dalam } \\
\text { DPT dan DPTb. } \\
\text { e) Menyerahkan kepada anggota KPPS 5: } \\
\text { 1) formulir Model C6-KPU untuk Pemilih } \\
\text { DPT. } \\
\text { 2) KTP-el/Suket/KK/Paspor/SIM untuk } \\
\text { Pemilih DPT yang tidak membawa } \\
\text { formulir Model C6-KPU. } \\
\text { 3) formulir Model A.5-KPU/A.5 LN-KPU } \\
\text { untuk Pemilih DPTb. } \\
\text { 4) KTP-el untuk Pemilih DPK. }\end{array}$ & Tidak ada \\
\hline KPPS 5 & $\begin{array}{l}\text { a) Meminta kepada Pemilih untuk mengisi } \\
\text { dan menandatangani sesuai identitas } \\
\text { Pemilih } \\
\text { ke dalam formulir: } \\
\text { 1) Model C7.DPT-KPU untuk Pemilih DPT. } \\
\text { 2) Model C7.DPTb-KPU untuk Pemilih } \\
\text { DPTb. } \\
\text { 3) Model C7.DPK-KPU untuk Pemilih } \\
\text { DPK. } \\
\text { b) Mempersilahkan Pemilih menempati }\end{array}$ & Tidak ada \\
\hline
\end{tabular}


tempat duduk yang telah disediakan.

c) Menyerahkan kepada anggota KPPS 2:

1) formulir Model C6-KPU untuk Pemilih DPT.

2) KTP-el/Suket/KK/Paspor/SIM untuk Pemilih DPT yang tidak membawa formulir Model C6-KPU.

3) formulir Model A.5-KPU/A.5 LN-KPU untuk Pemilih DPTb.

4) KTP-el untuk Pemilih DPK.

KPPS 6 Mengarahkan/memandu Pemilih memasukkan 1. Memberi isyarat atau tanda kepada Surat Suara sesuai dengan kotak suara masing- Ketua KPPS bahwa adanya bilik suara masing jenis Pemilu. yang kosong dan bisa digunakan Pemilih

2. Memandu Pemilih untuk Memasukkan surat suara sesuai jenis kotak suara dan selanjutnya memandu pemilih kearah meja tempat tinta untuk mencelupkan salah satu jari dan mengarahkan pemilih ke pintu keluar

KPPS 7 Meminta pemilih untuk mencelupkan salah 1. Memberi isyarat atau tanda kepada satu jari Pemilih ke dalam tempat tinta. Ketua KPPS bahwa adanya bilik suara yang kosong dan bisa digunakan Pemilih

2. Memandu Pemilih untuk Memasukkan surat suara sesuai jenis kotak suara dan selanjutnya memandu pemilih kearah meja tempat tinta untuk mencelupkan salah satu jari dan mengarahkan pemilih ke pintu keluar TPS.

3. Tugas Tersebut dilakukan secara bergantian dengan KPPS 6 sehingga mengurangi pemilih yang antri dalam TPS

Proses rekapitulasi suara yang telah dilakukan ada beberapa usulan atau rekomendasi yang dapat diberikan. Rekomendasi yang diberikan ada berupa perubahan posisi KPPSdan juga perubahan pembagian tugas antar KPPS, tujuan pembagian tugas tersebut adalah adanya keseimbangan kerja antar KPPSsehingga waktu yang diperkirakan untuk proses rekapitulasi surat suara tersebut bisa lebih cepat dari waktu yang telah ditetapkan, rincian rekomendari dari proses rekapitulasi dapat dilihat pada tabel 2 : 
Tabel 2. Tabel Rekomendasi Pembagian tugas KPPS Pada Proses Pemungutan Suara

\begin{tabular}{|c|c|c|}
\hline Jabatan & Tugas & Rekomendasi \\
\hline $\begin{array}{l}\text { Ketua } \\
\text { KPPS } 1\end{array}$ & $\begin{array}{l}\text { a) memimpin rapat penghitungan suara; dan } \\
\text { b) meneliti dan mengumumkan hasil } \\
\text { penelitian Surat Suara sah atau tidak sah } \\
\text { kepada Saksi, Pengawas TPS, Pemantau } \\
\text { Pemilu, Pemilih/Masyarakat yang hadir. }\end{array}$ & Tidak ada \\
\hline KPPS 2 & $\begin{array}{l}\text { a) Membuka setiap Surat Suara untuk diteliti } \\
\text { dan diumumkan oleh Ketua KPPS. }\end{array}$ & $\begin{array}{l}\text { Membuka setiap surat suara dan } \\
\text { membantu ketua KPPS dalam } \\
\text { mengarahkan ke titik pencoblosan di surat } \\
\text { suara tersebut }\end{array}$ \\
\hline KPPS 3 & $\begin{array}{l}\text { a) mencatat hasil penelitian tiap lembar Surat } \\
\text { Suara yang sudah diumumkan oleh } \\
\text { Ketua KPPS ke dalam formulir Model } \\
\text { C1.Plano-KPU sesuai jenis Pemilu; dan } \\
\text { b) memeriksa dan memastikan hasil } \\
\text { pencatatan sesuai dengan hasil yang } \\
\text { diumumkan oleh Ketua KPPS }\end{array}$ & $\begin{array}{l}\text { a) Menyalin data masing-masing } \\
\text { formulir Model C1.Plano ke dalam } \\
\text { masing-masing formulir Model C1 } \\
\text { hologram beserta salinannya sesuai } \\
\text { jenis Pemilu beriringan dengan } \\
\text { pencatatan pada C1 Plano oleh KPPS } \\
5 \text { dan } 6 . \\
\text { b) membuat Berita Acara Pemungutan } \\
\text { dan Penghitungan Suara di TPS } \\
\text { menggunakan formulir Model C-KPU } \\
\text { Hologram beserta Salinannya }\end{array}$ \\
\hline KPPS 4 & Tugas sama dengan KPPS 3 & $\begin{array}{l}\text { a) Menyalin data masing-masing } \\
\text { formulir Model C1.Plano ke dalam } \\
\text { masing-masing formulir Model C1 } \\
\text { hologram beserta salinannya sesuai } \\
\text { jenis Pemilu beriringan dengan } \\
\text { pencatatan pada C1 Plano oleh KPPS } \\
5 \text { dan } 6 . \\
\text { b) membuat Berita Acara Pemungutan } \\
\text { dan Penghitungan Suara di TPS } \\
\text { menggunakan formulir Model C-KPU } \\
\text { Hologram beserta Salinannya }\end{array}$ \\
\hline KPPS 5 & $\begin{array}{l}\text { Melipat Surat Suara yang telah diteliti dan } \\
\text { diumumkan oleh Ketua } \\
\text { masing-masing jenis Pemilu. }\end{array}$ & $\begin{array}{l}\text { a) mencatat hasil penelitian tiap lembar } \\
\text { Surat Suara yang sudah } \\
\text { diumumkan oleh Ketua KPPS ke } \\
\text { dalam formulir Model C1.Plano- } \\
\text { KPU sesuai jenis Pemilu } \\
\text { b) memeriksa dan memastikan hasil } \\
\text { pencatatan sesuai dengan hasil } \\
\text { yang diumumkan oleh Ketua KPPS }\end{array}$ \\
\hline KPPS 6 & $\begin{array}{l}\text { a) Menyusun, mengelompokan dan mengikat } \\
\text { dengan karet Surat Suara yang sudah } \\
\text { diteliti dan diumumkan: } \\
\text { 1) Surat Suara yang dinyatakan sah untuk } \\
\text { masing-masing Peserta Pemilu; dan } \\
\text { 2) Surat Suara yang dinyatakan tidak sah }\end{array}$ & $\begin{array}{l}\text { a) mencatat hasil penelitian tiap lembar } \\
\text { Surat Suara yang sudah } \\
\text { diumumkan oleh Ketua KPPS ke } \\
\text { dalam formulir Model C1.Plano- } \\
\text { KPU sesuai jenis Pemilu } \\
\text { b) memeriksa dan memastikan hasil } \\
\text { pencatatan sesuai dengan hasil } \\
\text { yang diumumkan oleh Ketua KPPS }\end{array}$ \\
\hline
\end{tabular}


KPPS 7 Tugas sama dengan KPPS 6 a) Menyusun, mengelompokan dan mengikat dengan karet Surat Suara yang sudah diteliti dan diumumkan:

1) Surat Suara yang dinyatakan sah untuk masing-masing Peserta Pemilu; dan

2) Surat Suara yang dinyatakan tidak sah

Untuk lebih jelasnya rekonstuksi pembagian tugas KPPS yang ada Indonesia untuk Pemilu selanjutnya pada saat pemungutan dan rekapitulasi berdasarkan hasil evaluasi yang telah dilakukan, maka dapat dilihat pada gambar dibawah ini :

Gambar 1. Rekomendasi Denah Pemungutan Suara
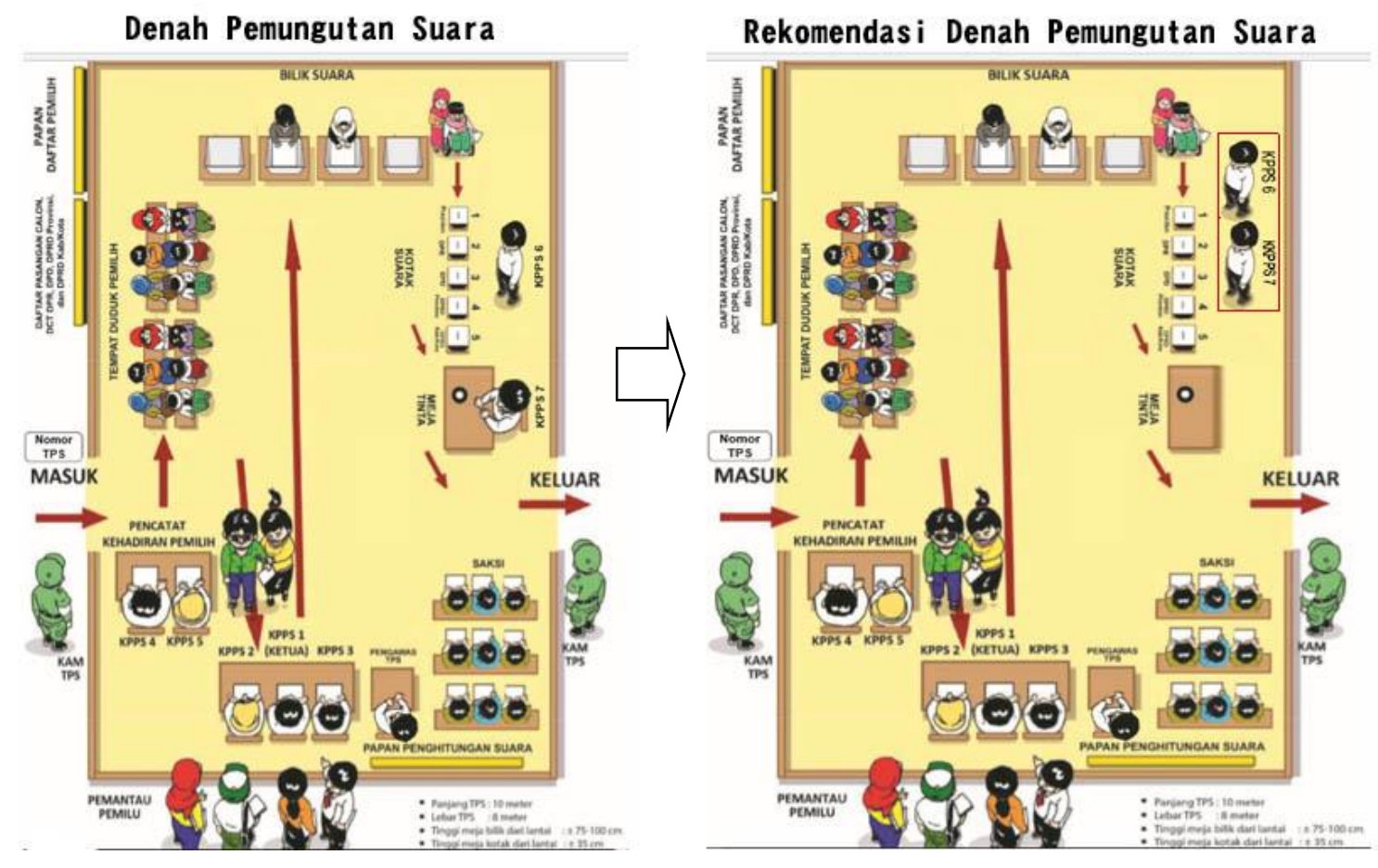
Gambar 2. Rekomendasi Denah Rekapitulasi Suara
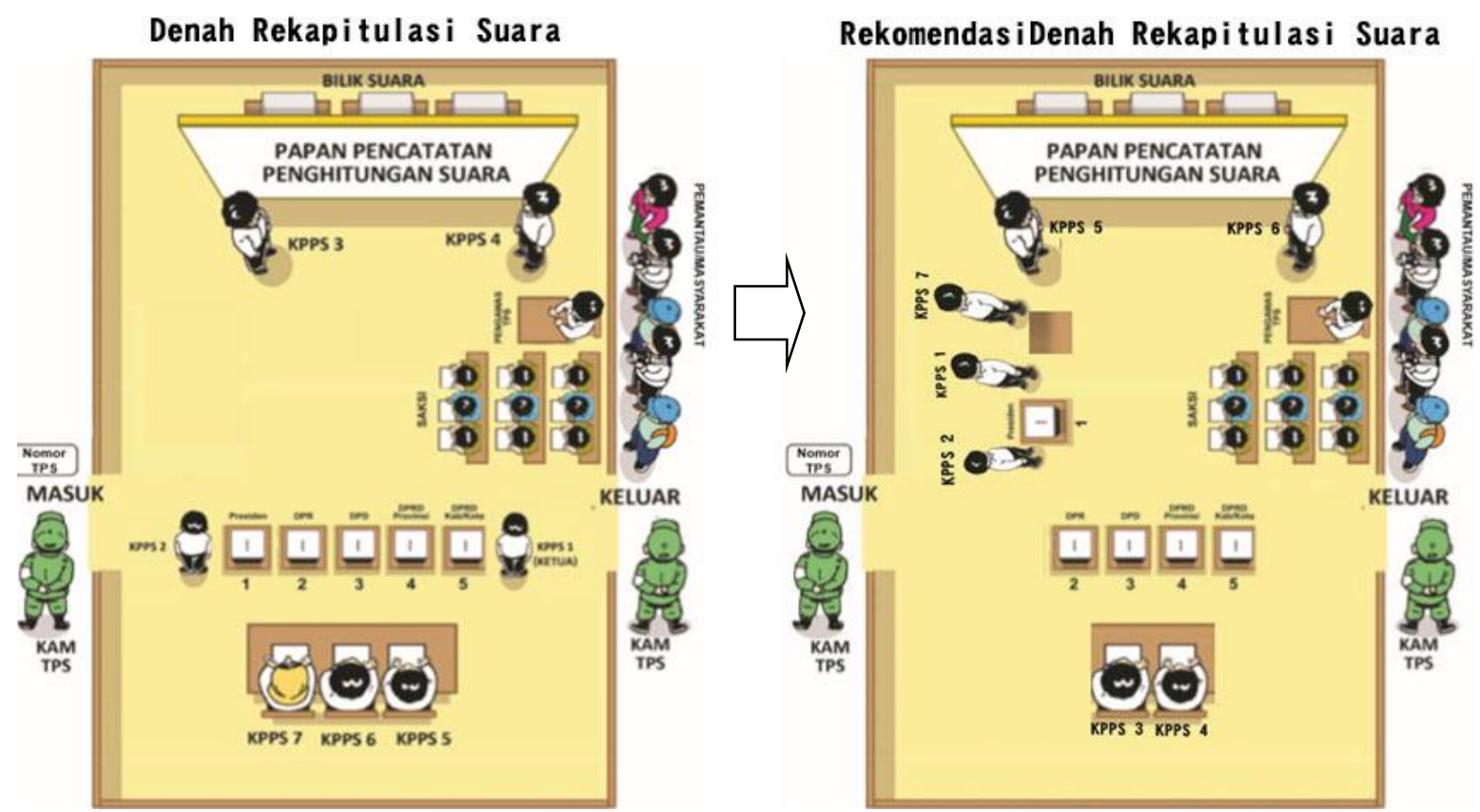

\section{PENUTUP}

Perubahan sistem pelaksanaan pemilihan umum di Indonesia secara fundamental dan komprehensif perlu dilakukan. Sistem pelaksanaan pemilu saat ini yang masih sangat manual dan sangat rumit membuat sulit para petugas penyelenggara pemilu (KPPS). Dampak dari kerumitan pembagian tugas KPPS yang tidak merata mengakibatkan banyaknya permasalahan yang dialami oleh KPPS pada Pemilu serentak Tahun 2019, sehingga akan berefek kepada hasil dari Pemilu itu sendiri menjadi diragukan dan juga akan berdampak kepermasalahan hukum. Baru kali ini dalam pelaksanaan pemilu yang banyak menjadi korban (meninggal atau bunuh diri) bukan pendukung calon yang kalah, namun malah Petugas KPPS yang menjadi korban.

Rekomendasi pada pembagian tugas dan wewenang terhadap KPPS berdasarkan standar hukum yang berlaku secara internasional yang menjamin hak pemilih dalam menyalurkan suaranya pada tulisan ini diharapkan merupakan suatu solusi efektif dalam hal efesiensi baik segi waktu maupun pembagian kerja yang merata. Diharapkan dengan adanya rekomendasi ini pertama, pada saat proses pemungutan suara dengan adanya perubahan tugas KPPS 6 dan KPPS 7 maka berakibat kepada perputaran yang dinamis pada saat pencoblosan karena bilik suara selalu diisi oleh pemilih yang akan mencoblos surat suara, sehingga antrian 
yang panjang pada saat pemungutan suara dapat dikurangi. Kedua, pada saat proses rekapitulasi suara diharapkan dengan pembagian tugas yang merata dan rekonstuksi ulang tugas KPPS maka waktu yang diperlukan dalam proses tersebut dapat lebih dipercepat, sehingga semua KPPS sama-sama saling bekerja dan berakibat kepada hasil kerja KPPS yang berkualitas dan tidak perlu lagi sampai larut malam bahkan sampai 24 jam dalah hal rekapitulasi tersebut.

\section{REFERENCES}

Harahap, N. (2014). Penelitian Kepustakaan. Iqra, 08(01), 68-73.

IDEA. (2002). Standar-standar Internasional untuk Pemilihan Umum. Stockholm: Author .

KPU. (2019). Panduan KPPS: Pemungutan dan Penghitungan Suara Pemilu 2019. Jakarta:Author.

Nasaruddin, N., Mone, A., \& Hamrun, H. (2017). Pengawasan Masyarakat Terhadap Pelaksanaan Pemilu Legislatif Tahun 2014 di Kabupaten Pangkep. Otoritas : Jurnal Ilmu Pemerintahan. https://doi.org/10.26618/ojip.v5i1.107

Pandiangan, A. (2019). Kelompok Penyelenggara Pemungutan Suara (KPPS) Pemilu 2019: Tanggungjawab Dan Beban Kerja. The Journal of Society \& Media, 3(1), 17.

Sugihariyadi, M., \& Rahardjo, J. (2015). Menakar Profesionalisme Penyelenggaraan Pemilu 2014 Di Kota Garam : ADDIN, 9(1), 107-128

Sugihariyadi, M., \& Rahardjo, J. (2015). Menakar Profesionalisme Penyelenggaraan Pemilu 2014 Di Kota Garam : ADDIN, 9(1), 107-128.

Surbakti, R., \& Karim, A. G. (2014). Integritas Pemilu 2014: Kajian Pelanggaran, Kekerasan, dan Penyalahgunaan Uang pada Pemilu 2014. Jakarta: Kemitraan bagi Pembaruan Tata Pemerintahan.

Surbakti, R., \& Nugroho, K. (2015). "Studi Tentang Desain Kelembagaan Pemilu yang Efektif." Jakarta: Kemitraan bagi Pembaruan Tata Pemerintahan.

Susanto, A. (2014). Disporprosionalitas Beban Tugas KPPS Studi Integritas Pemilu. Jurnal Politik Indonesia, 2(1), 9-19.

KPU RI (2017). Undang-Undang No. 7 Tahun 2017 Tentang Pemilihan Umum.Jakarta:Author.

\section{Website}

detiknews. (2019). KPU: Petugas KPPS yang Meninggal Bertambah Jadi 486 Orang. Retrieved fromhttps://news.detik.com/berita/d-4552632/kpu-petugas-kpps-yangmeninggal-bertambah-jadi-486-orang

klikpositif.com. (2019). Bawaslu Sebut Puluhan TPS Berpotensi PSU di Sumbar. Retrieved fromhttp://news.klikpositif.com/baca/49569/bawaslu-sebut-puluhan-tps-berpotensipsu-di-sumbar 
republika.co.id. (2019). JPPR Nilai Pemahaman KPPS Masih Minim. Retrieved fromhttps://republika.co.id/berita/pemilu/berita-pemilu/n41x5w/jppr-nilaipemahaman-kpps-masih-minim 